\title{
Obstetrics and Gynecology on Postage Stamps: A Philatelic Study
}

\author{
TURKAN GURSU1 and Alper Eraslan ${ }^{2}$
}

${ }^{1}$ SBU Zeynep Kamil Maternity and Pediatric Research and Training Hospital, Istanbul, TURKEY

${ }^{2}$ Dunya IVF, Kyrenia, Cyprus

May 5, 2020

\begin{abstract}
Objective:We tried to provide an overview of philatelic materials related to Gynecology and Obstetrics. Design:Sample philatelic materials including stamps, first day covers and stamped postcards, all related to obstetrics and gynecology, from the senior author's personal archive were grouped according to their titles and evaluated in detail. Setting:We examine how stamp designers use visual imagery to convey information to those who see, collect, and use stamps. Method:Sample philatelic materials, related to obstetrics and gynecology, were grouped according to their titles and evaluated in detail. Main outcome measures:Stamps dedicated to the Obstetrics and Gynecology are usually printed in order to (a)pay tribute to the pioneers of Obstetrics and Gynecology, (b)commemorate important Obstetrics and Gynecology Facilities\&Hospitals, (c)announce solid improvements and innovations in the field or (d)memorialize important meetings. Results:The initial use of postage stamps was solely to pay the fare of a postal service. Later on it was discovered that by using stamps it was possible to distribute ideas and news among people and also to inform them about developments, inventions, achievements and historical facts. Collecting Gynecology related philatelic materials is a very specialized branch of medical philately. In general, the subjects of the stamps dedicated to Obstetrics and Gynecology are, pioneers of Obstetrics and Gynecology, important Obstetrics and Gynecology Facilities\&Hospitals, solid improvements and innovations in the field and important meetings. Conclusion:Even though use of postage stamps is decreasing, they are still among the best mediums to convey messages to broad audience. Funding:None. Keywords:Commemoration, First Day Covers, Philately, Pionee
\end{abstract}

\section{Obstetrics and Gynecology on Postage Stamps: A Philatelic Study}

Short Title: A Form of Medical Philately

Corresponding Author: Turkan GURSU, MD

Affiliation: Department of Obstetrics and Gynecology, Zeynep Kamil Maternity and Pediatric Research and Training Hospital, Istanbul, TURKEY

Address: Opr. Dr. Burhanettin Üstünel Cad. No:10, Üsküdar, Istanbul, TURKEY

E-Mail: turkangursu@hotmail.com

Phone: +90 (533) 6836832

Author: Alper ERASLAN, MD

Affiliation: Department of Reproductive Endocrinology and Infertility, Dunya IVF Center, Kyrenia, Northern Cyprus

Address: Dunya IVF Center, Kyrenia, Northern Cyprus 
The Authors report no conflict of interest.

No funding was recieved for this article.

This article does not contain any studies with human participants or animals performed by any of the authors.

\section{Obstetrics and Gynecology on Postage Stamps}

\section{Structured Abstract:}

Objective: We tried to provide an overview of philatelic materials related to Gynecology and Obstetrics.

Design: Sample philatelic materials including stamps, first day covers and stamped postcards, all related to obstetrics and gynecology, from the senior author's personal archive were grouped according to their titles and evaluated in detail.

Setting: We examine how stamp designers use visual imagery to convey information to those who see, collect, and use stamps.

Method: Sample philatelic materials, related to obstetrics and gynecology, were grouped according to their titles and evaluated in detail.

Main outcome measures: Stamps dedicated to the Obstetrics and Gynecology are usually printed in order to (a)pay tribute to the pioneers of Obstetrics and Gynecology, (b)commemorate important Obstetrics and Gynecology Facilities\&Hospitals, (c)announce solid improvements and innovations in the field or (d)memorialize important meetings.

Results: The initial use of postage stamps was solely to pay the fare of a postal service. Later on it was discovered that by using stamps it was possible to distribute ideas and news among people and also to inform them about developments, inventions, achievements and historical facts.

Collecting Gynecology related philatelic materials is a very specialized branch of medical philately. In general, the subjects of the stamps dedicated to Obstetrics and Gynecology are, pioneers of Obstetrics and Gynecology, important Obstetrics and Gynecology Facilities\&Hospitals, solid improvements and innovations in the field and important meetings.

Conclusion: Even though use of postage stamps is decreasing, they are still among the best mediums to convey messages to broad audience.

Funding: None.

Keywords: Commemoration, First Day Covers, Philately, Pioneers of Obstetrics and Gynecology, Stamps.

Obstetrics and Gynecology on Postage Stamps

\section{Introduction}

When the first postage stamps were issued in the 1840s for the payment of postage fare, they frequently depicted the portrayals of royal figures like Queens, political figures like Presidents, and national pioneers. Shortly after the first postage stamps were introduced, other subjects and designs began to emerge, in order to inform people about pioneers, recent developments and achievements that made significant contributions to mankind ${ }^{1-4}$.

As a natural consequence, collectors were attracted by this area and philately, which by definition is simply known as collecting postage stamps, was born. Throughout years many thematic types of philately, such as industrial philately, historical philately, nature philately etc., emerged. Medical philately is known as collecting medicine related postage stamps and other philatelic materials such as first day covers and memory cards 5,6 . 
There are some studies about stamps, regarding orthopedics, anesthesia, cardiology, dentistry, anatomy, illnesses like tuberculosis, cancer, Down Syndrome and AIDS 4, 5, 7-14, or famous medical celebrities. Stamps dedicated to the Obstetrics and Gynecology field are usually printed in order to (a) pay tribute to the pioneers of Obstetrics and Gynecology, (b) commemorate important Obstetrics and Gynecology Facilities \& Hospitals, (c) announce solid improvements and innovations in the field and educate general public about a medical discovery or promote health programs, or (d) memorialize important meetings.

The daily use of postage stamps is decreasing due to the newer, faster and easier communication methods because of the recent technological developments, postage stamps are still among the best mediums to convey messages to broad audience.

In this study, we tried to provide an overview of philatelic materials related to Gynecolgy and Obstetrics.

\section{Methods}

Sample philatelic materials including stamps, first day covers and stamped postcards with special titles, all related to obstetrics and gynecology, from the senior author's personal archive was grouped according to their titles and evaluated in detail.

\section{Stamps Dedicated to the Pioneers of Obstetrics and Gynecology}

Since 1840s, it has become a tradition to honor important individuals on postage stamps. Postage stamp artists (designers and engravers) often optimize space for the image by minimizing texture. The general practice is to feature the portrait of the figure in full length or head alone, or the person is seen working. In some examples, the person may be represented by an image related to that person's life or invention, or subject-specific symbols. This provides a brief summary or history of the subject.

These stamps tell stories about the pioneers in Obstetrics and Gynecology and provide us a brief summary of the lives of some of the most influential figures in Obstetrics and Gynecology from a different viewpoint.

Ephraim McDowell (1771-1830), an American frontier physician, performed the first successful removal of an ovarian tumor in the world in $1809^{15}$. All attempts of laparotomy before 1809 had resulted in death due to peritonitis. McDowell emphasized on working "neat and clean" and he also removed the blood from the abdominal cavity during the operation and irrigated the intestines with warm water ${ }^{16}$. Thus, he has been called "the father of oophorectomy" and "the father of abdominal surgery"15.

In 1959, United States Postal Service commemorated McDowell with a 4-cent stamp and 6 First Day Covers, depicting his portrait and mentioning him being a pioneer surgeon and honoring his memory devoted to the 150th anniversary of the first successful abdominal operation (Fig. 1).

On July 1932, Hungary issued a series of stamps with portraits of some famous Hungarians, in one of which, Ignaz Semmelweis (1818-1865), who identified how puerperal sepsis was transmitted (it was a common and often fatal infection in the mid-19th-century) was commemorated ${ }^{17}$. He also revealed that, washing hands with chlorine could effectively reduce the incidence of puerperal sepsis and its mortality rate, letting him to be described as the "savior of mothers" 18 .

Issued in Hungary, the homeland of Semmelweis, the 4-Hungarian Forint stamp features portrait of Semmelweis, printed in color ultramarine, which is often considered the symbolic color of holiness and humility (Fig. 2B).

Another postage stamp, attributed again to Semmelweis was released in Hungary in 1954, a 20-Hungarian Forint stamp depicting portrait of him on foreground and demonstrating a puerperal scene on the background in olive brown. In this stamp; Semmelweis, standing with a newborn baby in his hands, a puerpera reaching out from her bed to her newborn baby, and in front of the bed the water pan and liquid needed to wash the hand in accordance with antisepsis rules, were illustrated (Fig 2A).

In 1965, Hungary commemorated the 100th anniversary of his death with another stamp, designed by Sandor Legrady, who depicted the portrayal of Semmelweis in red brown, also showing the "Rod of Asclepius", on the 
upper left corner (Fig 2C). The "Rod of Asclepius", which is the true and authentic symbol of Medicine, is a rod entwined by a single serpent, which is wielded by Asclepius, the Greek God of healing and Medicine ${ }^{19}$.

Oliver Wendell Holmes (1809 - 1894) was an American physician who, in 1843, published "The Contagiousness of Puerperal Fever", in which he argued with his colleagues that the cause of puerperal fever arises from patient to patient contact via their physicians ${ }^{20}$. In 1846, Holmes also invented the word "anesthesia", at first signifying insensibility to touch ${ }^{21}$.

In 1968, United States Post Office commemorated him with a 15-cent stamp and 6 First Day Covers as a part of the famous "Prominent American" Series. The stamp theme, which was designed by Richard Hurd and engraved by Albert Saavedra and Joseph S. Creamer Jr, is based on a photograph of him from National Photos that appeared in New York Times in 1951. They also honored him with a USPS Souvenir Page devoted to him (Fig 3).

William Harvey (1578-1657), an English physician, was the first to demonstrate the systemic circulation accurately in details in his book, "de Motu Cordis" in $1628^{22}$. As early as the 17th century he made important observations regarding the placenta, fetal circulatory system, fetal nourishment, and fetal respiration ${ }^{23}$. He found out the presence of ductus arteriosus and explained its function partially ${ }^{24}$. In 1651, he published "Exercitationes de Generatione Animalium" in which he supported epigenesis which is the gradual addition of parts, in contrary to the popular belief of preformationism in that period ${ }^{25}$.

In 1957, the Union of Soviet Socialist Republics (USSR) memorialized the 300th anniversary of his death with a 40-Kopeks portrayal stamp, which emphasizes a text saying "An outstanding English doctor who discovered blood circulation" that is devoted to his works (Fig 4A).

In 1959, Correo Argentino, Argentina's postal service, honored him with a bluish green stamp and 2 First Day Covers, printed for the "21st International Congress of Physiological Sciences" referring to his discovery of the circulation of the blood (Fig 4B).

On his 400th birth anniversary in 1978, USSR honored Harvey with a multicolored stamp, portrayed in green, with blue edges (Fig 4C). Also, two "Bowl of Hygieia" are depicted on the upper corners of the stamp, which is the symbol of pharmacy. In Greek mythology Hygieia, Asclepius's daughter, is the goddess of hygiene and cleanliness. The Hippocratic Oath which all physicians have taken for centuries is dedicated to Apollo, Asclepius, Hygieia and Panacea ${ }^{19}$.

In 1982, Republic of Transkei issued a series called Heroes of Medicine which focused on famous personalities of all times, who made important contributions to Medicine. They honored Harvey with a stamp printed for his contributions to the understanding of blood circulation. Designed by John Meyer, the stamp included a portrait of Harvey and a hand with its arterial anatomy shown on it (Fig 4D).

In 1987, Hungary issued a stamp series of "Great Pioneers in Medicine", one of which features the portrait of Harvey and a surreal human heart with many arterial branches, meticulously designed by Hungarian illustrator János Kass (1927-2010) (Fig 4E).

The Turkish physician, Besim Ömer Akalın (1862 - 1940), founder of modern obstetrics and gynecology in Turkey, took the lead in bringing the idea that a special education and formal training for nursery was mandatory to life ${ }^{26}$. He was against the repressive mindset which prevented Muslim women from contacting men, even for medical purposes. In 1911 he voluntarily trained many women, most of whom later provided skilled medical care for the wounded soldiers during World War 1. In 1922, Besim Ömer paved the way for first Turkish female physicians by enrolling them to the Imperial Medical College ${ }^{27}$.

In 1965, Turkey honored Besim Ömer's contributions to modern medicine with a 5-Kurus stamp, depicting his portrait in black and white, on a blue background (Fig 5).

Maria Cuțarida-Crătunescu (1857-1919), the first female physician in Romania, established the first Maternal Society in the country, which was dedicated to safeguard the welfare of the children in need, regardless of religion or ethnic origin. She actively served in the World War I ${ }^{28}$. 
She completed her thesis entitled "Hydrorrhea and its semiological value in cancer of the corpus of the uterus", at the Faculty of Medicine in Paris in 1884, being the first woman in Eastern Europe to earn her doctorate in medicine ${ }^{28}$.

In 2007, she was honored with a 80-Romanian Ban stamp. Designed by Octavian Penda, the stamp included a portrait of Cutarida-Crătunescu, a red cross and a "Bowl of Hygieia" (Fig 6). The symbol of the International Committee of the Red Cross was adopted at the Geneva Congress in 1864; in order to identify nonpartisan medical services and protect medical supplies and stations from any military attack during a conflict ${ }^{19}$.

Honoria Acosta-Sison (1888-1970), the first Filipino woman physician, did various researches in the field of eclampsia, choriocarcinoma and difficulties in parturition ${ }^{29}$. She was awarded with many awards and medals for her successful career ${ }^{30,31}$.

In 1978, the Philippines issued a commemorative 30-Philippine sentimo stamp with her name, portrait, the caduceus and the "Rod of Asclepius" (Fig 7).

The Caduceus or the "Staff of Hermes" features two snakes entwining a stick often depicted with two winglets. It is often mistakenly used as a symbol of medicine instead of the "Rod od Asclepius". Actually, the Caduceus emblem is associated with declamation, commerce, and negotiation. Misuse of the caduceus symbol became popular in the United States since 1902 as a result of documented mistakes, misunderstandings and confusion 19.

As a pioneering Chinese obstetrician and gynecologist, Lin Qiaozhi (1901 - 1983), did researches in the fields of placental abnormalities, fetal breathing, female pelvic diseases, gynecologic oncology and neonatal hemolytic disorders ${ }^{32}$. She personally delivered more than 50,000 babies in her career ${ }^{33}$.

On the seventh anniversary of Lin's death in 1990, a stamp printed in China from the "Scientists" issue shows Gynecologist Lin Qiaozhi, in 1990, depicting her portrait and a fetus in the womb.

Sir James Simpson (1811 - 1870), a Scottish obstetrician, was the first to use chloroform for anesthetic purposes in humans and he pioneered its use at birth ${ }^{34}$. Like Besim Ömer, he defended the idea of using midwives in the hospitals. In order to aid dystocia, he developed the design of an obstetric forceps, that to date known as "Simpson Forceps" (Fig 8B) ${ }^{35}$.

In 1992, Transkei issued a 65-cent stamp to honor Sir James Simpson. The stamp, designed by Johan Van Niekerk, depicts him and a midwife applying chloroform to a patient in the labour room (Fig 8A).

Marie Heim-Vögtlin (1845 - 1916) was the first female Swiss physician and was one of the founders of the first Swiss gynecologic hospital. In 2016, the hundredth anniversary of her death is commemorated with a Swiss Post stamp (Fig 9) ${ }^{36}$.

Virginia Apgar (1909 - 1974) was an American anesthesist who introduced obstetrical considerations to the established field of neonatology ${ }^{29}$. In 1952, she developed a scoring system for infants, which evaluates the health of an infant immediately after birth in order to determine the need for an immediate intervention, the need for resuscitation and the effects of resuscitation ${ }^{37}$. Since many studies confirmed the strong relationship between low APGAR scores, neonatal mortality, degree of asphyxia, and neurological outcomes; this scoring system rapidly became standart across the globe in order to assess the condition of an infant ${ }^{38}$.

In 1994, she was honored by the United States Postal Service with a 20-cent Great Americans series postage stamp (Fig 10).

\section{Stamps Dedicated to the Important Obstetric and Gynecology Facilities \& Hospitals}

Yusuf Kamil Bey (1808-1876), appointed by the Ottoman Palace to the service of Egyptian Governor Kavalalı Mehmed Ali Pasha in Cairo, married Zeynep Hanm (1825-1884), the youngest daughter of the Pasha. They didn't have children, in return they became parents of many orphans. In 1860, the couple bought a plot of land in Istanbul to establish a hospital with 100 beds, named Zeynep Kamil Hospital, which is now one of the oldest health care institutions of Istanbul, and has been able to maintain health service to date. Zeynep 
Kamil Hospital is a specialized hospital for Obstetrics \& Gynecology, in which patients are cured for free. For the past 50 years, the number of births registered in this hospital is approximately $1,200,000{ }^{39}$.

In 1960, a stamp with a breastfeeding puerpera was printed in Turkey to commemorate Zeynep Kamil Hospital's 100th anniversary, as well as its contributions to obstetrics \& gynecology (Fig 11).

Princess Maria Luisa decided on establishing the first specialized Obstetrics and Gynecology hospital in Bulgaria in 1883 and funded the establishment. "Maichin Dom", meaning "Mothers' Home" in Bulgarian, was officially opened in $1903^{40}$.

In 2015, this well-established institution was commemorated by the Bulgarian post office on its 111th anniversary with a 0.65 -Bulgarian lev stamp. Designed by Teodor Liho, the stamp depicts the hospital building, a portrait of Princess Maria Luisa, a fetus in utero and multiple red crosses symbolizing nonaligned medical service for victims of war.

\section{Stamps Announcing Solid Improvements and Innovations and Educating General Public about a Medical Discovery or Promoting Health Programs}

The first IVF baby, Louise J Brown, was delivered in Oldham England in 1978 using extracorporeal fertilization (In Vitro Fertilization-IVF), developed by obstetrician and gynecologist Patrick Steptoe (1913-1988), physiologist Robert Edwards (1925-2013), and nurse and embryologist Jean Purdy (1945-1985) ${ }^{41}$. Since this first successful example which was a major milestone in the treatment of infertile couples, the use of IVF has spread throughout the world due to factors such as the trend for postponing childbearing, the significant drop in the number of people trying to conceive ${ }^{42}$.

The media referred Brown as a "test tube baby" ${ }^{43}$. In 1999, Patients' Tale (Millennium Series - 3rd Set) Presentation Pack was issued by the Royal Mail, which comprised of four stamps. One of these four stamps depicts the photograph of the Sculpture of Test-tube Baby in cast iron sculpted by Antony Gormley, which represents the development of in vitro fertilization (Fig 12). Also 2 postcards of each stamp; 2 First Day covers were issued.

This contributed social consciousness and raise awareness of this newly established treatment option for infertility which affects approximately $15 \%$ of couples.

Georgios Nikolaou Papanikolaou (1883 - 1962), a Greek cytopathologist, found that cancerous tumors of the cervix could be discovered and diagnosed by examining cells found in vaginal secretions under the microscope 44. He invented the cervical cancer screening "Pap Smear" test, one of the greatest developments in medicine, which is widely used worldwide and resulted in a significant decline in cervical cancer incidence and mortality 45 .

In 1978, Papanikolaou's work was honored by the US Postal Service with a 13-cent stamp to draw attention to early cancer detection (Fig 13). Designed by Paul Calle, the stamp depicts Papanikolaou placing a slide under objectives lens of a microscope.

In 2004, Correo Argentino, Argentina's postal service, point out the importance of "Pap Test" by issuing a 75-centavo stamp, which put emphasis on prevention of the cervical cancer by performing "Pap Test" in advance.

In 2004, Australia Post issued stamps recognizing five Australian Innovations, which now became a part of everyday life around the world ${ }^{46}$. "Ultrasound Imaging Equipment 1976" was one of these stamps, which was designed by Mike Heine and printed by SNP Sprint (Fig 14). This stamp was dedicated to George Kossoff and colleagues, who pioneered the widespread adoption of ultrasound worldwide ${ }^{47-50}$.

The stamp depicts a pregnant woman holding an image of an ultrasound just next to her abdomen, and three people from a distance standing in the sea, most probably attributed to the Australia's spectacular natural beauties.

\section{Stamps Announcing or Memorializing Important Meetings}


Occasionally, post offices issue commemorative stamps and First Day Covers, devoted to scientific meetings or events. A First Day Cover is a specially designed envelope, carrying a newly printed stamp, along with a specially designed postmark, on it.

Obstetrics and Gynecologic meetings or congresses such as; 5th World Congress of Obstetrics and Gynecology in Australia in 1967, 3rd International Gynecology Days in Portugal in 1973, 8th Latin America Congress in Havana in 1976, 8th National Congress of Obstetrics and Gynecology in Romania in 1979, 9th World Congress of Obstetrics and Gynecology in Japan in 1979, 11th World Congress of Obstetrics and Gynecology in Berlin in 1985, 10th Asian \& Oceanic Congress of Obstetrics and Gynecology in Sri Lanka in 1985, Safe Motherhood South Asia Conference in Lahore in 1990, 18th FIGO World Congress of Obstetrics and Gynecology in Malaysia in 2006 and 57th All India Congress of Obstetrics and Gynecology in Patna in 2014 were honored by special stamps or First Day of Issues (Fig 15, 16).

\section{Results}

Stamp designers use visual imagery to convey information to those who see, collect, and use stamps. Philatelic materials, including postage stamps, first day covers and stamped postcards related to Obstetrics and Gynecology also have an impact in conveying various information in this area among populations.

\section{Discussion}

Main findings

Until today, postal services of different countries have released various philatelic materials related to Obstetrics and Gynecology, with different messages.

\section{Strengths and Limitations}

This study is about philatelic materials related to Obstetrics and Gynecology and the sample materials mentioned are from the senior author's personal collection. The authors believe there are various other similar philatelic materials not mentioned in this study.

Interpretation

Postage stamps may be regarded as real artworks with many aspects. Art designers and engravers create them. Stamps are not solely for paying the fare of a post but also to distribute the message included on it among people. Philatelic materials, including stamps, first day covers and stamped postcards related to Obstetrics and Gynecology, are also used to disseminate messages in this area.

The daily use of postage stamps is decreasing due to the newer, faster and easier communication methods because of the recent technological developments. The future of philatelic materials is uncertain.

\section{Conclusion}

Philately is often mistakenly seen only as a hobby however, it can also be used as a tool to interact with the public or as a reminder tool to commemorate certain people, institutions, and innovations. Although fewer commemorative stamps are being used today, they spread and promote ideas, and they also act as a medium to deliver messages about particular topics to the general public.

The subject of a stamp with a medical theme may help us draw attention of many people who send and receive mail to a particular subject, through its easy-to-understand structure. It may also help us clarify and summarize the visual history of our medical practice by showing important people, facilities, innovations or events in our area of expertise.

Although the information on the stamp can not contain extensive information about the subject, this does not limit its importance. Even though the educational value of stamps with special themes is underestimated, medical philately can be used as an important and inexpensive way to present a subject or an idea as it can transmit information effectively and easily. It also reminds medical professionals like us of certain people, institutions, innovations or events. 


\section{References}

1: Lefrere JJ, Danic B. Transfusion, blood donation, and postage stamps: a worldwide review. Transfusion. 2010 Aug;50(8):1838-48.

2: Praestholm J, Dissing I, Herning M. Radiology on postage stamps. Radiographics. 1988 Sep;8(5):981-6.

3: Afshar A. Honoring Avicenna, the great Persian physician on the world's postage stamps. Arch Iran Med. 2010 Sep;13(5):447-53.

4: Gursu S, Yildirim T, Sahin V, Tok E. Art in Science: orthopaedics through philatelic material. Clin Orthop Relat Res. 2013 Dec;471(12):3755-9.

5: Rangappa P. History of analgesia and regional anesthesia through philately. Anaesth Intensive Care. 2008 Jul;36 Suppl 1:12-8.

6: Afshar A. A brief Iranian medical history through commemorative postage stamps. Arch Iran Med. 2010 Mar;13(2):161-5.

7: Afshar A. Concepts of orthopedic disorders in Avicenna's Canon of Medicine. Arch Iran Med. 2011 Mar;14(2):157-9.

8: Davies MK, Hollman A. Stamps in cardiology. Millennium stamps. Heart. 2006 Feb;92(2):146.

9: Loevy HT, Kowitz AA. Dentistry on stamps: A commemorative stamp on Dental Health. J Hist Dent. 2008 Spring;56(1):44.

10: O'Rahilly R. Philatelic introduction to the history of anatomy. Clin Anat. 1997;10(5):337-40.

11: Shampo MA, Rosenow EC 3rd. A history of tuberculosis on stamps. Chest. 2009 Aug;136(2):578-582.

12: Taub M. Cancer stamps: 50 years in the crusade against cancer through stamps. CA Cancer J Clin. 1978 May-Jun;28(3):164-9.

13: Ataman AD, Vatanoğlu-Lutz EE, Yıldırım G. Medicine in stamps: history of Down syndrome through philately. J Turk Ger Gynecol Assoc. 2012 Dec 1;13(4):267-9.

14: Vatanoglu EE, Ataman AD. A sexually transmitted disease: History of AIDS through philately. J Turk Ger Gynecol Assoc. 2011 Sep 1;12(3):192-6.

15: Bowra JM. Making a man, a great man: Ephraim McDowell, ovariotomy and history. Social Change in the 21st Century Conference. Centre for Social Change Research, Queensland University of Technology, Carseldine, Brisbane. 28 October 2005.

16: Othersen HB Jr. Ephraim McDowell: the qualities of a good surgeon. Ann Surg. 2004 May;239(5):64850.

17: Noakes TD, Borresen J, Hew-Butler T, Lambert MI, Jordaan E. Semmelweis and the aetiology of puerperal sepsis 160 years on: an historical review. Epidemiol Infect. 2008 Jan;136(1):1-9.

18: Ataman AD, Vatanoğlu-Lutz EE, Yıldırım G. Medicine in stamps-Ignaz Semmelweis and Puerperal Fever. J Turk Ger Gynecol Assoc. 2013 Mar 1;14(1):35-9.

19: Shetty A, Shetty S, Dsouza O. Medical Symbols in Practice: Myths vs Reality. J Clin Diagn Res. 2014 Aug; 8(8): PC12-PC14.

20: Lane HJ, Blum N, Fee E. Oliver Wendell Holmes (1809-1894) and Ignaz Philipp Semmelweis (1818-1865): preventing the transmission of puerperal fever. Am J Public Health. 2010 Jun;100(6):1008-9.

21: Tubbs RS, Shoja MM, Loukas M, Carmichael SW. Oliver Wendell Holmes, Sr. (1809-1894): physician, jurist, poet, inventor, pioneer, and anatomist. Clin Anat. 2012 Nov;25(8):992-7. 
22: Ribatti D. William Harvey and the discovery of the circulation of the blood. J Angiogenes Res. 2009 Sep 21;1:3.

23: Dunn PM. Dr William Harvey (1578-1657): physician, obstetrician, and fetal physiologist. Arch Dis Child. 1990 Oct;65(10 Spec No):1098-100.

24: Aird WC. Discovery of the cardiovascular system: from Galen to William Harvey. J Thromb Haemost. 2011 Jul;9 Suppl 1:118-29.

25: Gilbert SF. Chapter 1: Developmental Anatomy. Developmental Biology, 9th Edition. Sinauer Associates, Inc. 2010. pp:12-14.

26: Erdemir AD. Ondördüncü Yüzyıldan Günümüze Kadar Türk Tıbbı. Tıp Tarihi. Nobel. 2014. pp:113194.

27: Kavak M. Besim Omer Pasa ve Ailesinin Hususi Evraki. Atis S, Cekin MD. Sağlık Tarihi ve Müzeciliği Sempozyumu. Secil. 2018. pp:407-431.

28: https://en.wikipedia.org/wiki/Maria_Cuțarida-Crătunescu

29: Ogilvie M, Harvey J. Acosta-Sison, Honoria (1848-?). The Biographical Dictionary of Women in Science: Pioneering Lives From Ancient Times to the Mid-20th Century Vol 1. Routledge. 2000. p:11

30: https://en.wikipedia.org/wiki/Honoria_Acosta-Sison

31: http://www.oocities.org/scientists_phil/sisonlifeandcareer.html

32: https://en.wikipedia.org/wiki/Lin_Qiaozhi

33: Ogilvie M, Harvey J. Lin Qiaozhi (Lin Chiao-Chi) (1901-1983). The Biographical Dictionary of Women in Science: Pioneering Lives From Ancient Times to the Mid-20th Century Vol 2. Routledge. 2000. pp:790-91.

34: Agasti TK. Ch 15: Inhalational Anaesthetic Agents. Textbook of Anesthesia for Postgraduates. Jaypee. 2011. pp:395-397.

35: Sukhera Sheikh, Inithan Ganesaratnam, Haider Jan. The birth of forceps. JRSM Short Rep. 2013 Jul; 4(7): $1-4$.

36: https://en.wikipedia.org/wiki/Marie_Heim-Vögtlin

37: Apgar V, A Proposal for a New Method of Evaluation of the Newborn Infant. Originally published in July 1953, volume 32, pages 250-259. Anesth Analg. 2015 May;120(5):1056-9.

38: Jay V, On a historical note: Dr. Virginia apgar. Pediatr Dev Pathol. 1999 May-Jun;2(3):292-4.

39: Etker S, Gunergun F, Kose A. Zeynep-Kamil Hastanesi'nin Kuruluşu ve Vakfiyesi. Osmanlı Bilimi Araştırmaları. 2004 Vol 5, Nr 2, pp:1-37.

40: https://maichindom.com/en/about-us/history/

41: Edwards RG. The beginnings of human in vitro fertilization. Gardner DK, Weissman A, Howles CM, Shoham Z. Textbook of Assisted Reproductive Techniques 5th Edition Vol 2 Clinical Perspectives. CRC. 2018. pp:xiii-xxv.

42: Inhorn MC, Patrizio P. Infertility around the globe: new thinking on gender, reproductive technologies and global movements in the 21st century. Hum Reprod Update. 2015 Jul-Aug;21(4):411-26.

43: Dow K. Looking into the Test Tube: The Birth of IVF on British Television. Med Hist. 2019 Apr;63(2):189-208.

44: Tan SY, Tatsumura Y. George Papanicolaou (1883-1962): Discoverer of the Pap smear. Singapore Med J. 2015 Oct;56(10):586-7. 
45: Shaw PA. The History of Cervical Screening I: The Pap. Test. J Soc Obstet Gynaecol Can. 2000 Feb;22(2):110-14.

46: Australian Innovations postage stamp series. Ultrasound Imaging 1976. 2004

47: Campbell S. A short history of sonography in obstetrics and gynaecology. Facts Views Vis Obgyn. 2013;5(3):213-29.

48: Griffiths KA. An historical look at ultrasound as an Australian innovation on the occasion of the ultrasound stamp issued by Australia Post - 18 May 2004. ASUM Ultrasound Bulletin 2004 August 7:3: $22-26$.

49: Robinson DE, Garrett WJ, Kossoff G. Fetal anatomy displayed by ultrasound. Invest Radiol. 1968 Nov-Dec;3(6):442-9.

50: Garrett WJ, Grunwald G, Robinson DE. Prenatal diagnosis of fetal polycystic kidney by ultrasound. Aust N Z J Obstet Gynaecol. 1970 Feb;10(1):7-9.

\section{Figure Legends}

Fig 1. The US Postal Service commemorated Ephraim McDowell with a stamp and a First Day Cover in 1959 .

Fig 2. Hungary issued stamps attributed to Ignaz SemmelweisA. Semmelweis, illustrated as holding a newborn baby beside a water pan and liquid for antisepsis. B. portrait of Semmelweis, printed in color ultramarine C. Semmelweis and the "Rod of Asclepius", the authentic symbol of Medicine.

Fig 3. Oliver Wendell Holmes was commemorated by the US Postal Office with a stamp, a First Day Cover and a Souvenir Page.

Fig 4. William Harvey was honored by many countries at various times with stamps regarding his contributions to systemic circulation.A. USSR stamp commemorated him in his 300th anniversary of his death B. Argentina's postal service honored his discovery of the circulation of the blood with a stamp printed for the "21st International Congress of Physiological Sciences" C. Harvey and two "Bowl of Hygieia" are depicted which is the symbol of Pharmacy is depicted in the stamp D. A 1982 stamp depicting Harvey and a hand with its arterial anatomy E. The meticulously designed stamp depicting Harvey and a surreal human heart with many arterial branches

Fig 5. Besim Ömer Akalın was commemorated by Turkey with a stamp regarding his contributions to modern Obstetrics and Gynecology in Turkey.

Fig 6. Romanian stamp shows Maria Cuțarida-Crătunescu along with a red cross and a "Bowl of Hygieia".

Fig 7. Philippines issued a stamp showing Honoria Acosta-Sison along with the caduceus and the "Rod of Asclepius".

Fig 8. A. Sir James Simpson was honored with a stamp depicting him in the labour room applying chloroform. B. Simpson Obstetrical Forceps

Fig 9. The Swiss Post commemorated Marie Heim-Vögtlin with a stamp in the hundredth yar of hre death in 2016 .

Fig 10. Virginia Apgar, founder of the APGAR scoring system, was honored by the USPS with a stamp in 1994.

Fig 11. Turkey issued a stamp commemorating Zeynep Kamil Hospital's 100th anniversary in 1960.

Fig 12. The IVF treatment, one of the most important medical innovation in Obstetrics and Gynecology in the 21th century, was the subject of the stamp issued by Royal Mail in 1999. 
Fig 13. The USPS honored Georgios Nikolaou Papanikolaou with a stamp for his contributions to his invention of the cervical cancer screening test.

Fig 14. Australia commemorated Kossof and colleagues for their contributions to the ultrasound imaging in 2004 .

Fig 15. Stamps devoted to important Obstetrics and Gynecologic meeting. A. The 3rd International Gynecology Days in Portugal in 1973 B. The 8th National Congress of Obstetrics and Gynecology in Romania in 1979 C. The 5th World Congress of Obstetrics and Gynecology in Australia in 1967 D. The 11th World Congress of Obstetrics and Gynecology in Berlin in 1985E. The 8th Latin America Congress in Havana in 1976 F. The 10th Asian\&Oceanic Congress of Obstetrics and Gynecology in Sri Lanka in 1985 G. Safe Motherhood South Asia Conference in Lahore in 1990

Fig 16. Stamps devoted to important Obstetrics and Gynecologic meeting. A. The 57th All India Congress of Obstetrics and Gynecology in Patna in 2014 B. The 18th FIGO World Congress of Obstetrics and Gynecology in Malaysia in 2006

\section{Hosted file}

Fig 1.jpg available at https://authorea.com/users/302727/articles/432812-obstetrics-andgynecology-on-postage-stamps-a-philatelic-study

\section{Hosted file}

Fig 2.jpg available at https://authorea.com/users/302727/articles/432812-obstetrics-andgynecology-on-postage-stamps-a-philatelic-study

\section{Hosted file}

Fig 3.jpg available at https://authorea.com/users/302727/articles/432812-obstetrics-andgynecology-on-postage-stamps-a-philatelic-study

\section{Hosted file}

Fig 4.jpg available at https://authorea.com/users/302727/articles/432812-obstetrics-andgynecology-on-postage-stamps-a-philatelic-study

\section{Hosted file}

Fig 5.jpg available at https://authorea.com/users/302727/articles/432812-obstetrics-andgynecology-on-postage-stamps-a-philatelic-study

\section{Hosted file}

Fig 6.jpg available at https://authorea.com/users/302727/articles/432812-obstetrics-andgynecology-on-postage-stamps-a-philatelic-study

\section{Hosted file}

Fig 7.jpg available at https://authorea.com/users/302727/articles/432812-obstetrics-andgynecology-on-postage-stamps-a-philatelic-study

\section{Hosted file}

Fig 8.jpg available at https://authorea.com/users/302727/articles/432812-obstetrics-andgynecology-on-postage-stamps-a-philatelic-study

\section{Hosted file}

Fig 9.jpg available at https://authorea.com/users/302727/articles/432812-obstetrics-andgynecology-on-postage-stamps-a-philatelic-study 


\section{Hosted file}

Fig 10.jpg available at https://authorea.com/users/302727/articles/432812-obstetrics-andgynecology-on-postage-stamps-a-philatelic-study

\section{Hosted file}

Fig 11.jpg available at https://authorea.com/users/302727/articles/432812-obstetrics-andgynecology-on-postage-stamps-a-philatelic-study

\section{Hosted file}

Fig 12.jpg available at https://authorea.com/users/302727/articles/432812-obstetrics-andgynecology-on-postage-stamps-a-philatelic-study

\section{Hosted file}

Fig 13.jpg available at https://authorea.com/users/302727/articles/432812-obstetrics-andgynecology-on-postage-stamps-a-philatelic-study

\section{Hosted file}

Fig 14.jpg available at https://authorea.com/users/302727/articles/432812-obstetrics-andgynecology-on-postage-stamps-a-philatelic-study

\section{Hosted file}

Fig 15.jpg available at https://authorea.com/users/302727/articles/432812-obstetrics-andgynecology-on-postage-stamps-a-philatelic-study

\section{Hosted file}

Fig 16.jpg available at https://authorea.com/users/302727/articles/432812-obstetrics-andgynecology-on-postage-stamps-a-philatelic-study 